\title{
Profiling minorities: police stop and search practices in Toronto, Canada
}

\author{
Yunliang Meng* \\ Central Connecticut State University, USA
}

This paper explores police stop and search practices in Toronto using the 2003-2012 data from Toronto Police Service. The findings demonstrate that for black youth, the number of stops and the stops/arrests ratios increased significantly by $42.7 \%$ and $44.9 \%$ respectively between 2003 and 2012, while for white youth, both indices decreased steadily during the same period. Moreover, they show that police stops of black youth occur most excessively in neighbourhoods where more white people reside and/or have higher crime rates. This article argues for the importance of a contextualized examination of police stops within the spatial context of neighbourhoods and calls for open and free access to police stop data, regular internal review by police, and community policing in Toronto.

Key Words: police stops, black youth, GIS, Toronto.

Article Info: Received: December 1, 2016; Revised: April 11, 2017; Accepted: May 5, 2017; Online: May 25, 2017.

\section{Introduction}

Consistent with the trend of declining crime rate in Canada, the crime rate in Toronto has dropped by $42 \%$ between 2001 and 2012 and the city has the lowest crime rate among the 33 metropolitan areas in Canada (Matteo, 2014). Criminology researchers are struggling to list all the causes for why the crime rate is down in Toronto, but part of the decrease can be attributed to changes in policing methods that have been more proactive with respect to crime prevention and also more resource intensive given the broader range of community and police interactions required (Matteo, 2014). The Toronto Police Service

\section{* Correspondence address}

Address: Central Connecticut State University, 1615, Stanley Street, New Britain, Connecticut, 06053, USA.

Phone: +1-860-832-2789 | Email: mengy@ccsu.edu

(C)2017 Human Geographies; The authors

(c) (i) This work is licensed under a

Creative Commons Attribution 4.0 International License. DOI:10.5719/hgeo.2017.111.1 
(TPS) has made proactive policing a priority by implementing programs that reinforce police patrols in high crime rate areas. Meanwhile, resources have been poured into TPS. It is reported that the per capita cost of policing in Toronto has increased $14 \%$-- to $\$ 387$ per resident in four years, which is twice the inflation rate regardless of the declining crime rate (Kari, 2014).

The significant increase in police resources being accompanied by a decrease in the crime rate is certainly a welcoming result (Matteo, 2014). However, the role of policing in Toronto's crime decline has been the subject of contentious debate for well over a decade. In Toronto, the last decade witnessed an increase in proactive policing strategies such as crime analysis, problem-oriented policing and community partnerships that are believed to be the right tactics for solving crime issues. One of the touchy and controversial aspects of proactive policing strategies in Toronto involves "randomly" stopping and questioning people in a street encounter.

The stop and search practices are a vital way for police to collect intelligence on suspicious activities and persons and deter real criminals from committing offences, but the practices can be intrusive, harassing, even intimidating for people being stopped and searched. Moreover, the claim of racial bias in police stop and search practices has become a particularly controversial issue in recent years. For example, blacks in Toronto have long complained about what has come to be known as 'racial profiling', since they are frequently stopped, questioned and searched by the police for "DWBBs - Driving While Being Black Violations" (Foster, 1996, p. 5). Such claim was supported by the research showing that, between 2008 and 2012, 23,627 of black males were stopped and documented by the TPS - within the patrol zone in which they live - for purposes of "general investigation" (Wortley, 2013). The stoppage number accounts for $22 \%$ of the total black male population in Toronto. Racial bias affects black people at every age group, but black youth are more likely to be targeted, since race-based stereotypes attribute a greater propensity for antisocial behaviour to them (Eid et al., 2011). In Toronto, Wortley's (2013) research suggested that about $80 \%$ of black youth between the ages of 15 and 24 have been stopped by police for purposes of "general investigation" during the year of 2008 and 2013. By contrast, allegations of racial bias in police stops have, in most cases, been repeatedly denied by TPS (see Tanovich, 2007; Winsa and Rankin, 2012). To defend their actions, Toronto police have emphasized that blacks, especially Black youth, are overrepresented in police stop and search data because they are more likely to be involved in homicides and in crimes involving drugs and firearms (Toronto Police Service, 2010).

Unfortunately, the research of racial bias in police stop and search practices in Toronto, is fairly limited, largely because there was a complete ban on the collection and release of all race-crime data in Canada (see Owusu-Bempah and Miller, 2010). In other words, unlike the United States, Canadian researchers do not have easy and regular access to official data on the race of people stopped and searched by the police. As a result, most of the previous research is lack of large sample size empirical data to support the racial bias claim or detect changes in police stop and search practices over time (see James, 1998; Neugebauer, 2000; Ontario Human Rights Commission, 2003; Eid et al., 2011). In addition, much of the research on police stops in Toronto has tended to 
ignore the spatial variation in police stops and its association with neighbourhood characteristics, which are vital for understanding racial bias in police stops across different neighbourhoods within the city. Furthermore, previous research has not deeply examined the experiences of black youth who are at great risk of being stopped by police and compared the experiences of black youth with those of their white counterparts. Therefore, this study attempts to contribute to the literature on police stop and search practices in Toronto by examining: 1) the racial disparity in police stops and its changing trend between 2003 and 2012; and 2) whether and how the racial disparity patterns are spatially associated with neighbourhood characteristics.

\section{Research background}

\section{Hot spots policing}

In the past decade, hot spots policing, as a variant of problem-oriented policing that emphasizes spatial location in understanding crime (Weisburd and Braga, 2003), has gained considerable attention in the study of criminality. The key idea behind the hot spots policing is that a relatively small number of places in a city called hot spots - account for a disproportionately large number of crime. Therefore, "the more precisely patrol presence is concentrated at the 'hot spots' and 'hot times' of criminal activity, the less crime there will be in those places and times" (Sherman and Eck, 2002: 308). Motivated by hot spots policing, crime mapping and analysis is widely used by law enforcement agencies, to map, visualize, and analyze crime patterns. Indeed, Braga (2005: 317) found that " 7 in 10 departments with more than 100 sworn officers reported using crime mapping to identify crime hot spots," making hot spots policing one of the most popular crime reduction strategies. The policing activities associated with hot spots policing are directed patrol, heightened traffic enforcement, and aggressive disorder enforcement (Braga, 2005). Many police departments now report having the capability to manage and analyze crime data in sophisticated ways for implementing problem-solving strategies to control hot spot locations (Weisburd et al., 2003) and TPS is no exception. For example, in 2012, Chief Bill Blair released a set of internal crime hot spot maps that are instantly readable. Toronto police use the maps to choose where to deploy officers and concentrate their efforts, including the documentation of citizens in mostly non-criminal encounters (Ranking and Winsa, 2012). Chief Bill Blair insisted with the help of the technology, police are targeting crime-rampant areas and that stopping and documenting people who move about those areas is good police work (Ranking and Winsa, 2012).

\section{Concerns regarding police stops and 208 cards in Toronto}

Toronto police stop and question hundreds of thousands of people, both walking and driving, every year in the streets. In many cases, police officers fill out a 208 card which is used as a way to "get to know" the neighbourhood, according to Chief Bill Blair. In reality, it is an open secret that 208 cards have been used by Toronto 
police as part of a strategy to record information about persons the police consider to be of interest (Morton, 2015). The police may also use it to inquire into intimate family information of stopped people, and the individuals he or she is linked with. It should be noted that 1), nowhere does a 208 card indicate the criminal activity for which the individual is being stopped, since most stops initiated by Toronto police for carding purposes have nothing to do with real criminal behaviour but are done to collect information (TPAC, 2012); 2) the police do not stop everyone they see, and they do not write up a 208 card on everyone they stop (TPAC, 2012). In other words, at individual or neighbourhood level, who gets stopped, and who gets written up are completely under the police discretion.

The Toronto police claim that the data they obtain by use of these cards are an invaluable tool in fighting crime - for example, in identifying known criminal associates, the whereabouts of known suspects and disproving false alibis. For many residents in Toronto, 208 cards are a form of racial profiling done under the guise of fighting crime whereby certain sectors of the community are targeted for more police scrutiny than others and stopped more frequently on the basis of their race. Although Toronto police constantly denied the existence of racial profiling in the stop and search practice, they did acknowledge that the social cost of obtaining a contact card with little-to-no value to public safety or crime prevention is detrimental to the TPS and may contribute to a loss of public confidence and trust (Ranking and Winsa, 2013).

However, research on 208 cards is very limited, largely because researchers in Canada previously had no access to the 208 card database until the Star had to take the TPS to the Court of Appeal. Finally, TPS released the data in 2009. In an explosive series of articles during 2010 and 2014, reporters for the Toronto Star, led by Jim Rankin, published their analysis that shows that black youth are 2.5 times more likely to be stopped than white youth, three times more likely to be charged with a driving offence, three times more likely to be held in jail rather than released (see more at www.thestar.com/racematters). However, in Rankin's analysis, the efficiency of police stops - that is, the rate at which crime is detected leading to an arrest - was missing and it failed to show the changing trend in police stops overtime.

\section{Police stops, crime, race and location}

Previous studies on police stop and search suggest that both the racial background of the suspect and the racial composition of the neighbourhood where the police interact with the suspect influence police decision to stop and search a suspect (Bittner, 1970; Reiss, 1971). At the neighbourhood level, the level of the crime rates is a good indicator of the level of stop and search. Guided by different research showing that crime prevention effectiveness is maximized when police focus their resources on where the problems are located, hot spots policing is considered as an appropriate method to allocate police resources and dictate how police respond to calls and patrol the city (Braga, 2007). As the police's effort to reduce crime rates in crime-rampant areas, more police patrols are unsurprisingly deployed to neighbourhoods that have more reported crimes (Doerner, 1997). Consequently, increased is the likelihood of local residents' contact with the police or the chance of local residents being stopped by the police (Roh and Robinson, 2009; Stults et al., 
2010). Thus, as an evil twins, disproportionately more police stops and high crime rates are likely to be spatially associated.

It should be noted that crime rampant areas are often intersected with socioeconomically disadvantaged neighbourhoods housing a high percentage of racial minorities (e.g. Roh and Robinson, 2009; Stults et al., 2010). Therefore, people, including police, may replace racial characteristics of neighbourhoods for racial backgrounds of individuals in their cognitive schema of suspicion, and, more important, act on them (Fagan et al. 2010). Quillan and Pager (2001) found that urban residents' perceptions of crime in their neighborhoods are significantly correlated with the percentage of Black youth, even after crime levels and other neighborhood characteristics are controlled for. Police perceptions may be similarly skewed, resulting in elevated stop rates in neighborhoods with high percentages of minority populations, and the pathway is through the translation of perceptions into neighborhood stigma. Therefore, disproportionately more police stops are likely to be spatially correlated with racial minority neighbourhoods with high crime rates.

In an urban environment, a suspect's race interacting with neighbourhood characteristics can help police officers form suspicion (Thompson, 1999; Meehan and Ponder, 2002; Smith et al., 2006). Meehan and Ponder (2002) suggested that in a predominantly white suburban area adjacent to a larger city, black drivers are more likely to be subject of mobile data terminal queries (an indicator for suspicion), and that queries about black people increased with distance from the city. The authors concluded that "racial profiling is inextricably tied not only to race, but to officers' conceptions of place of what should typically occur in an area and who belongs as well as where they belong" (Meehan and Ponder, 2002: 402). This is because geographic concentration of disadvantage is very pronounced in minority neighbourhoods, so police officers tend to suspect that racial minorities might be engaged in criminal activities when they appear in white and wealthy neighbourhoods. As a result, disproportionately more stops of minorities are likely to happen in white dominated and affluent neighbourhoods with lower crime rates. Since a few studies have explored the spatial dimension of policing in Toronto, this study will examine the spatial association among police stops, crime rates, and racial characteristics of neighbourhoods.

\section{Benchmark methods}

The race-specific arrest data is considered as an improved benchmark in the studies of police-citizen contacts (see Gelman et al., 2007; Ridgeway and Macdonald, 2010, Meng, 2014). For example, the index is a ratio, so base error or aggregation error cannot be introduced in the calculation process. By adopting this index, there is no faulty assumption that police stops should be randomly conducted, since the index is created under the logic that police stops are conducted to detect crimes, or in other words, police stops and crimes are expected to be correlated. In addition, the index provides a quantitative assessment regarding the efficiency of police stops to detect wrongdoing and sanction offenders. The larger the index, the lower the efficiency. Therefore, race-specific crime data is used in this study as the benchmark to determine whether the racial disparity exists in the police stop and search practices in Toronto. 
This study first explores the efficiency of street stops to detect wrongdoing and sanction offenders between 2003 and 2012 by posing the following hypothesis:

H1: As police stops have become more prevalent in recent years, are the stops substantially more likely to lead to arrests for black and white youth?

Given the possible relationship among the racial disparity in police stops, neighbourhood racial characteristics, and crime rates, this study examines the following hypotheses:

$H 2 a$ : The racial disparity is greater in youth contact with the police, as the level of racialization and crime rate increase?

$H 2 b$ : The racial disparity is greater in youth contact with the police, as the level of racialization and crime rate decrease?

\section{Methodology}

\section{Studyarea}

The city of Toronto lies on the northwest shore of Lake Ontario, the easternmost of the Great Lakes (Figure 1). It is the largest city in Canada and the provincial capital of Ontario. According to the 2011 National Household Survey (NHS), about 1 in every 5 visible minority people in Canada lives in the city of Toronto and $49.1 \%$ of Toronto's population reported themselves as being part of a visible minority group, up from $46.9 \%$ in 2006 and $42.8 \%$ in 2001 . The City of Toronto's visible minority population has increased by $8.75 \%$ since 2006 , and by $20.3 \%$ since 2001 . Given the racial diversity and the fact that it is home to over half of the nation's black population (Chui et al. 2008), Toronto is a particularly important geographic location in which to conduct a study of racial bias in policing.

\section{Data and analytic approach}

The ten-year (2003 - 2012) police stop data were gathered from Field Information Report or well known as 208 cards. The first five-year (2003 - 2007) data include details on contact ID, Person ID, age, gender, stoppage location, contact date, birth place, and skin colour (i.e.: Black, White, Brown, and Other) of each stop incident. Besides the variables listed above, the second five-year (2008 - 2012) data include details on nature of contact (i.e. drug, general investigation, loitering, and traffic etc.) and home location of stopped people. Arrest and charge data were from Toronto police arrest and charge data collected in the field between 2003 and 2012. This dataset contains information regarding age, gender, charge category, arrest time, skin colour, case ID, and location of arrest for each arrestee. It should be noted that the variables such as stoppage location, and location of arrest are at the police patrol zone level. There are 73 police patrol zones in Toronto (see Figure 1). The city's racial composition data were gathered from 2006 census data at Census Tract level. Instead of the most recent 2011 census data, 2006 census data were used, because it is widely recognized that the 2011 census data gathered by a voluntary survey are not of the same quality as the previous mandatory long form. Racial groups considered in this study are blacks and whites and this study included only youth between the ages of 15 and 24 (U.N. definition of youth). 


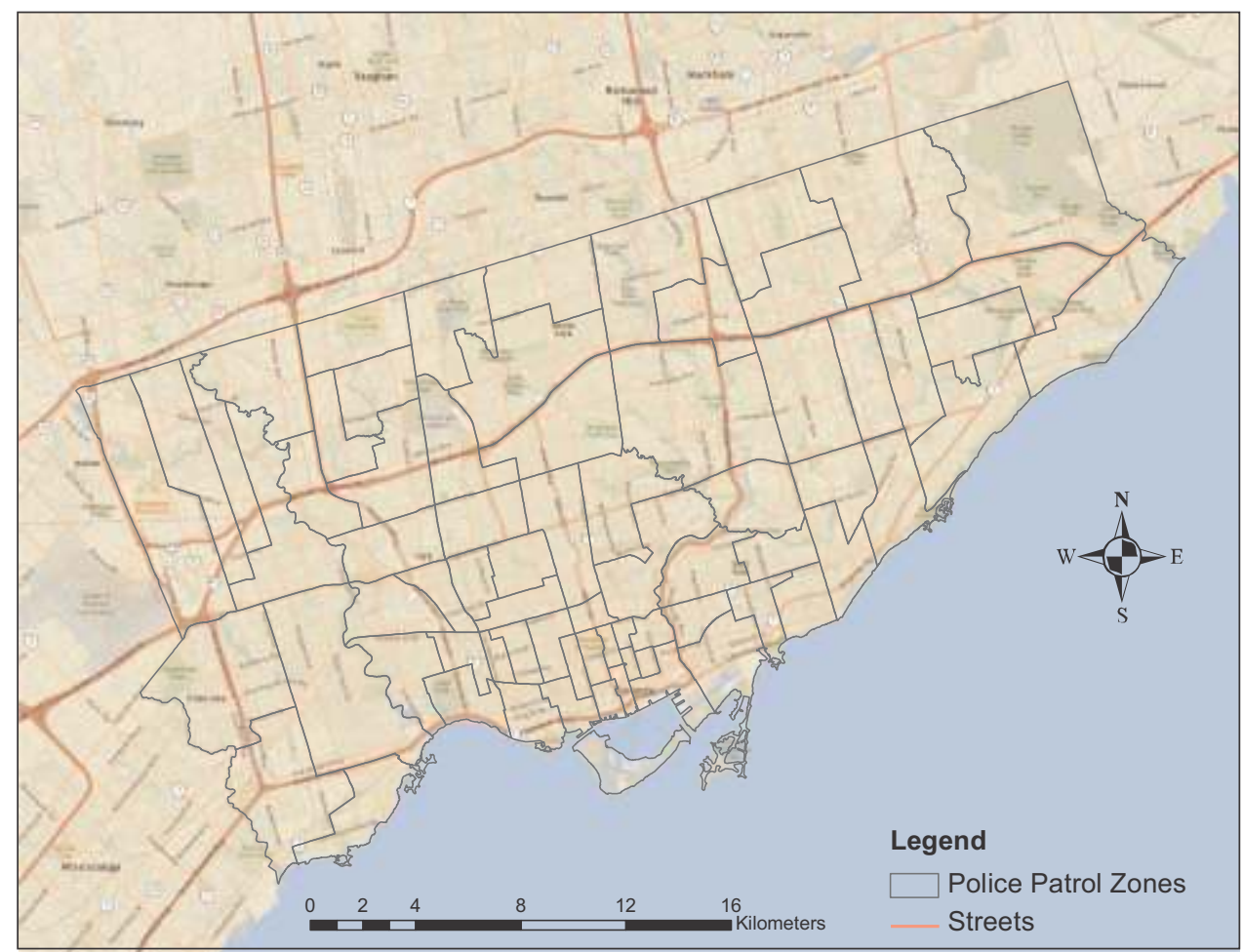

Figure 1. Study area

Since 'race' is not a category in the Canadian census of population, this study used the 'visible minority' variable (see Table 1) to identify black population in each Census Tract (CT) in Toronto. White population in each CT was quantified using the non-visible minority population minus the aboriginal population. The level of racialization in each CT was represented by the percentage of whites in the residential population. The crime rates at the CT level in Toronto in 2006 were obtained from the Canadian Centre for Justice which collects police-reported crime statistics through the Uniform Crime Reporting Survey (UCR). Racial composition and crime rate data at CT level were carefully aggregated to the level of police patrol zone for neighbourhood level analysis using the "Areal Interpolation" tool provided by ArcGIS (Beyer, 2004). Although a police patrol zone is not explicitly considered as a neighbourhood, police patrol zone boundaries have been widely used in extant research as a unit of analysis that corresponds to actual neighbourhood boundaries (Roh and Robinson, 2009). Hence, Toronto police patrol zone boundaries were used as actual neighbourhood boundaries in this study.

To calculate stops/arrests ratios for black or white youth at neighbourhood level, the number of stops against black and white youth in 2006 was divided by the number of arrests against black or white youth during the same year in each police patrol zone. A high race-specific stops/arrests ratio indicates broadened suspicion of individuals based on race and therefore the efficiency of street stops to detect wrongdoing is low. A low race-specific stops/arrests ratio suggests under-stops of a racial group or the efficiency of street stops to detect wrongdoing is high. Then, the racial disparity in police stops at neighbourhood level was measured by dividing 
Table 1. Visible minorities as \% of population in Toronto

\begin{tabular}{lc}
\hline Visible Minority & $\begin{array}{c}\text { Percentage of Total } \\
\text { Population } \mathbf{( 2 0 1 1} \text { Census) }\end{array}$ \\
\hline South Asian & $12.3 \%$ \\
\hline Chinese & $10.8 \%$ \\
\hline Black & $8.5 \%$ \\
\hline Filipino & $5.1 \%$ \\
\hline Arab/West Asian & $2 \%$ \\
\hline Latin American & $3.1 \%$ \\
\hline Southeast Asian & $1.8 \%$ \\
\hline Korean & $1.4 \%$ \\
\hline Japanese & $0.5 \%$ \\
\hline Visible minority, n.i.e. & $1.3 \%$ \\
\hline Multiple & $1.5 \%$ \\
\hline Total & $\mathbf{4 9 . 1 \%}$ \\
\hline
\end{tabular}

the stops/arrests ratios for black youth by the stops/arrests ratios for white youth. The bivariate global Moran's I statistic (Anselin, 2003) is applied to test the null hypothesis that values on the racial disparity in police stops, neighbourhood racial characteristics and crime rates are not geographically related, meaning distributed randomly over the study area. In addition to testing spatial autocorrelation globally, a spatial clustering analysis is applied to identify the areas where the racial disparity in police stops, neighbourhood racial characteristics and crime rates are spatially overlapped.

\section{Results}

\section{Descriptive statistics}

The stops and arrests of black youth practiced by Toronto police are shown in Figure 2. Although at the city level the number of arrests of black youth had been very stable, around 8,000 each year between 2003 and 2012, the number of stops practiced on black youth had increased significantly from 24,672 in 2003 to 47,669 in 2007, an increase of 93.2\% since 2003. During 2008 and 2012, the number of stops against black youth indeed dropped from its all-time high of 47,669 in 2007 to 35,199 in 2012 , but the 2012 's number still represents an increase of $42.7 \%$ since 2003. The stops and arrests of white youth between 2003 and 2012 are shown in Figure 3. At the city level the number of arrests of white youth had been consistently decreasing from 12,472 in 2003 to 9,282 in 2012, a drop of 25.6\% in 10 years. Meanwhile, the number of stops practiced on white youth had first increased significantly from 63,937 in 2003 to 101,976 in 2007, an increase of 59.5\% since 2003, but during 2008 and 2012, the number of stops against white youth had been consistently dropping from its all-time high of 101,976 in 2007 to 46,119 in 2012 and the 2012 stoppage number represents a decrease of $27.9 \%$ since 2003.

As shown in Figure 4, the stops/arrests ratio is 5.13 for white youth and 3.21 for black youth at the city level in the year of 2003. In other words, on average, Toronto police needed to stop 5.13 white youth before they finally make one arrest against 


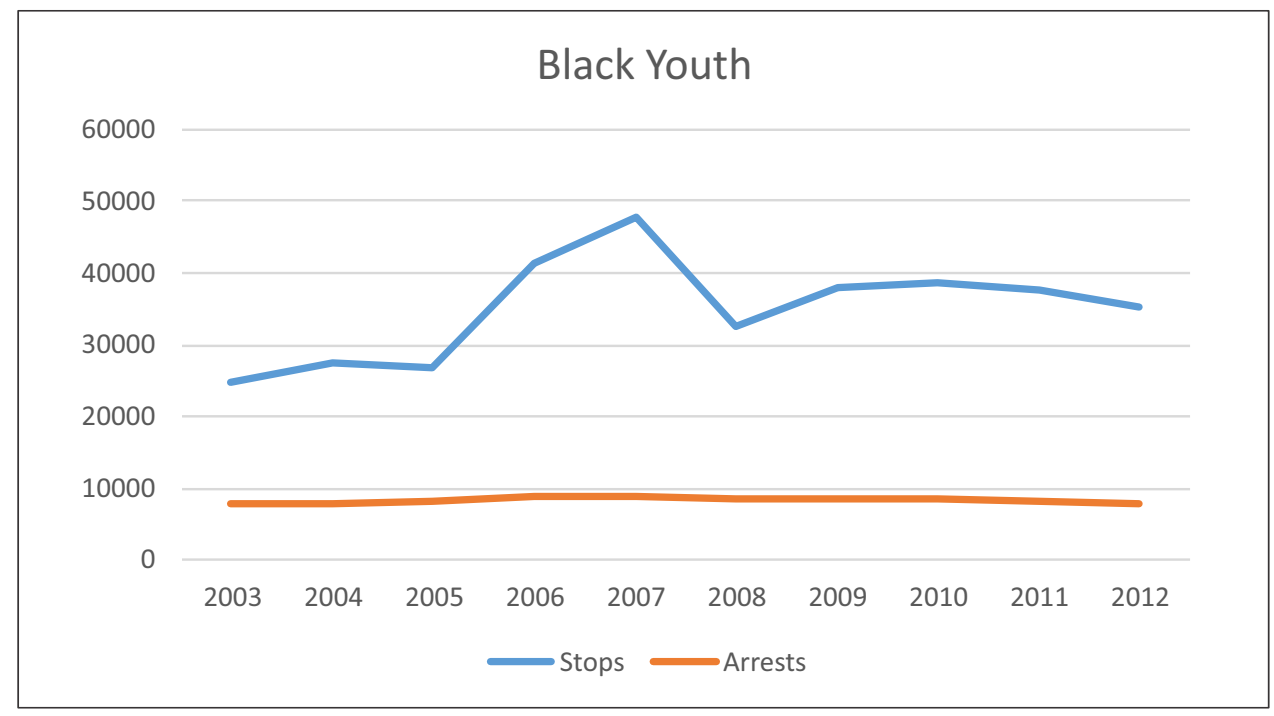

Figure 2. The stops and arrests of black youth in Toronto during 2003 and 2012

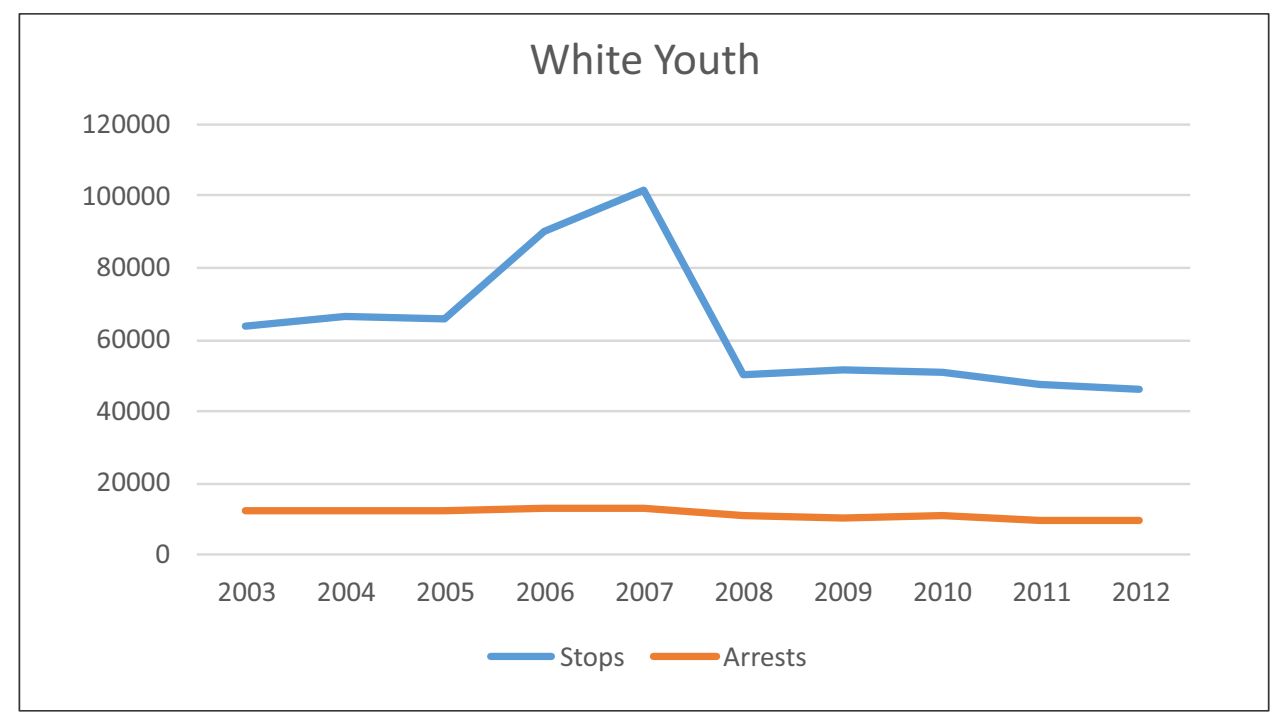

Figure 3. The stops and arrests of white youth in Toronto during 2003 and 2012

white youth, but they only needed to stop 3.21 black youth before they arrest a black youth in 2003. By comparing the two ratios, it is clear that white youth were more likely to be stopped by Toronto police and the efficiency of street stops to detect wrongdoing of white youth was low in the year of 2003. However, the gap has significantly narrowed after the year of 2007 and, in 2012, the stops/arrests ratio for white youth (4.96) was just marginally higher than black youth (4.62). It should be noted that during 2003 and 2012, the stops/arrests ratio for white youth had been slightly dropped by $3.3 \%$, from 5.13 to 4.96 , while the stops/arrests ratio for black youth had been significantly increased by $44.9 \%$, from 3.21 to 4.62 during the same period. 


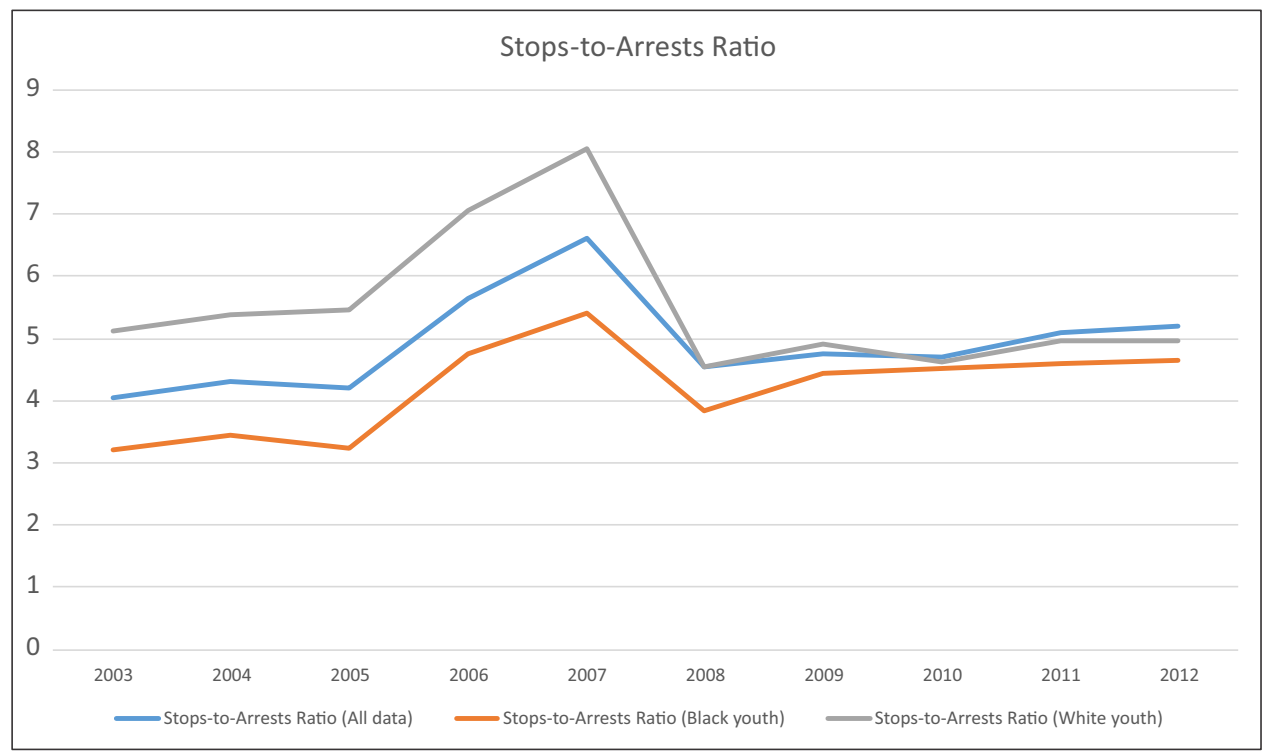

Figure 4. The stops-to-arrests ratios for black and white youth in Toronto during 2003 and 2012

Table 2. Bivariate Global Moran's I values for the racial disparity in police stops, neighbourhood racial characteristics and crime rates

\begin{tabular}{lc}
\hline & The Racial Disparity in Police Stops \\
\hline White Population (\%) & $0.412^{* *}$ \\
\hline Crime Rate (per thousand) & $0.358^{*}$ \\
\hline${ }^{* *}$ Spatial autocorrelation is significant at $p<0.01$ & \\
${ }^{*}$ Spatial autocorrelation is significant at $\mathrm{p}<0.05$ & \\
\hline
\end{tabular}

\section{Spatial clustering of racial disparity in police stops}

As criminal behaviours, police stops in Toronto are not expected to be randomly distributed. Rather, as mentioned above, this study hypothesizes the racial disparity in police stops in Toronto tend to be higher in areas where certain neighbourhood racial characteristics and crime patterns are also present. The Bivariate global Moran's I statistics show a medium and positive spatial correlation between the racial disparity in police stops and the percentages of whites in the population and a statistically significant spatial correlation between the disparity and crime rate measured at the neighbourhood level ( Table 2). The results suggest that disproportionately more stops against blacks are more likely to happen in less racialized neighbourhoods and/or neighbourhoods with higher crime rates.

In addition to testing the spatial association globally for the variables, LISA (Local Indicator of Spatial Association) cluster maps (Anselin, 2003) were used to illustrate the geographic clustering of the stops/arrests ratios and neighbourhood racial and socio-economic characteristics. For example, the similarity or dissimilarity of the crime rates in neighbourhoods near locales is determined by the LISA statistics at $\mathrm{p}<0.05$ (Anselin, 2003) and displayed by the LISA cluster maps, which show five different types of spatial association (see Figure $5 \mathrm{~b}$ for example): (1) high-high, for neighbourhoods with high crime rates that are also in close 
A. Spatial clustering of the racial disparity in police stops and the percentages of White people in the residential population

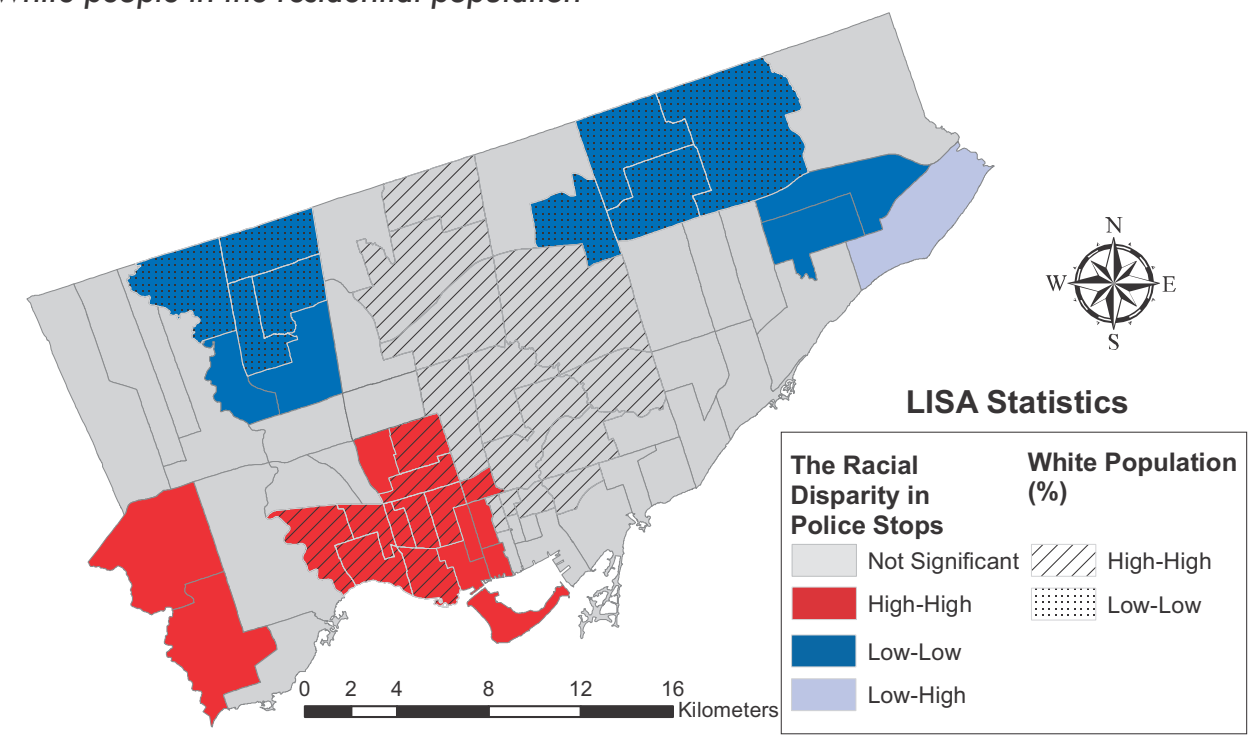

B. Spatial clustering of the racial disparity in police stops and crime rates

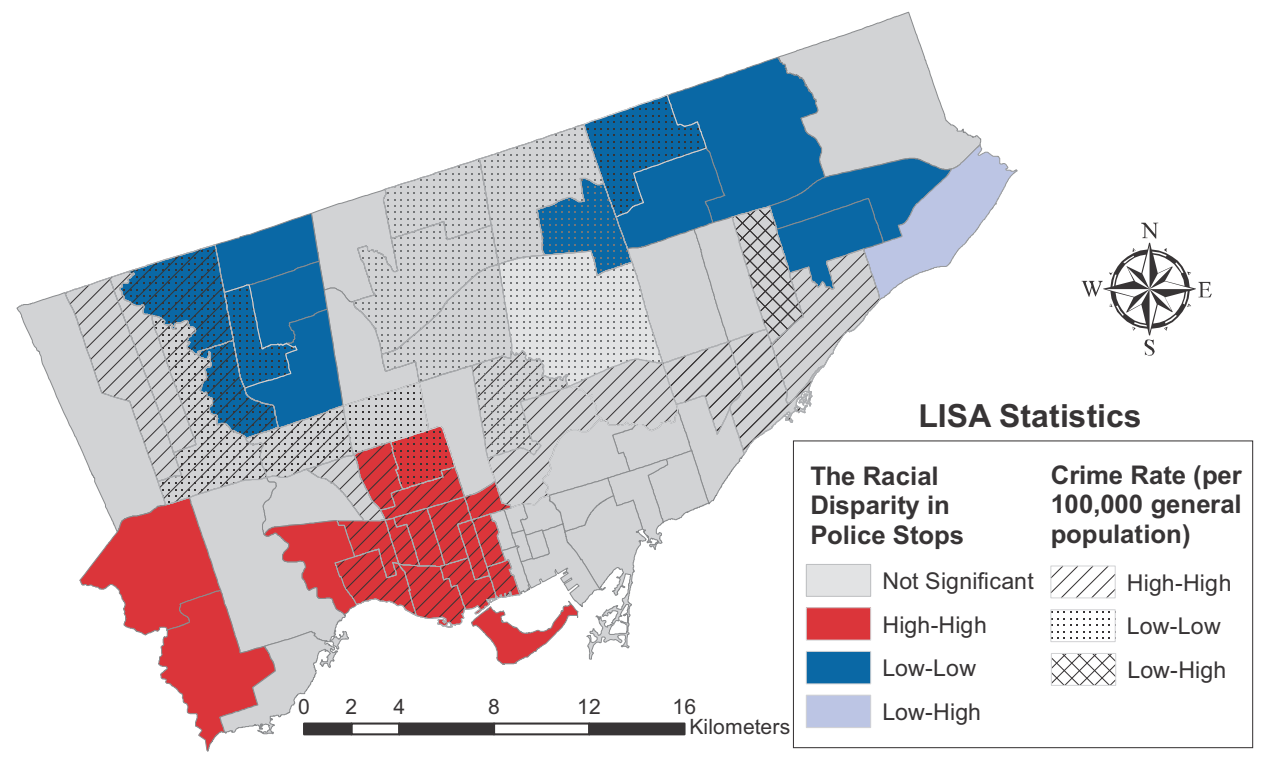

Figure 5. LISA cluster maps of the racial disparity in police stops, the percentages of white people in the residential population, and crime rates

proximity to neighbourhoods with high crime rates; (2) low-low, for neighbourhoods with low crime rates that are also in close proximity to neighbourhoods with low crime rates; (3) high-low, for neighbourhoods with high crime rates but are proximate to neighbourhoods with low crime rates; (4) lowhigh, for neighbourhoods that have low crime rates, yet are in close with proximity to neighbourhoods with high crime rates; (5) not significant, for neighbourhoods where there is no statistically significant spatial clustering. In this study, neighbouring patrol zones are determined by queen contiguity, whereby any 
patrol zones sharing either boundaries or vertices are regarded as neighbours. Then, generated is the same spatial typology for the racial disparity in police stops, and the percentage of white people in the residential population.

To demonstrate the degree of overlap between the spatial clustering of the racial disparity in police stops and the levels of racialization, and between the spatial clustering of the racial disparity in police stops and crime rates, the LISA clusters of the racial disparity in police stops are overlaid with the LISA clusters of the levels of racialization and crime rates measured at the neighbourhood level. (see Figure $5 \mathrm{a}$ and $5 \mathrm{~b}$ ). The Figure $5 \mathrm{a}$ and $5 \mathrm{~b}$ show that the clusters of high racial disparity in police stops tend to be in areas where there is spatial clustering of high percentages of whites in the residential population and/or high crime rates. Although police officers stop individuals for different reasons, not only to arrest, but also, for example, to obtain information for other crimes, the findings here do reveal a significant amount of police and black youth interactions in neighbourhoods housing a high percentage of whites and/or having high crime rates in Toronto. Also, this finding suggests a considerable amount of police discretion in terms of stopping black youth suspects rather than their white counterparts in the white dominated and/or high crime rate neighbourhoods in Toronto. Conversely, the clusters of low racial disparity in police stops tend to occur in areas where there are clusters of low percentages of whites in the population and/or low crime rates (see Figure $5 \mathrm{a}$ and $5 \mathrm{~b}$ ). In other words, compared with their white counterparts, black youth arouse less suspicion from police in racialized and/or low crime rate neighbourhoods and, therefore, tend to be stopped less often in those areas.

\section{Discussion}

Access to police data and democratic racism

Police stops are often considered as an appropriate way to generate a cheap form of intelligence (Fagan et al., 2010). Intelligence was the traditional utility of the data generated in the course of stops and searches of citizens and the data were not shared with the general public or researchers in Toronto. For years, the 208 cards generated by stops of citizens sat in file drawers in precincts and were examined as police searched for suspects when crime happened. In 2008, under Chief Bill Blair, data collected from carding stops can be entered directly into a computer. The 208 cards became known as "Field Information Reports", which were to be filled out by officers for any person or vehicle of interest during the course of their duties.

However, access to the police stop data in Canada has been always difficult. In the past, there was a complete ban on the collection and release of all race-crime statistics, including all data related to the processing of minorities through the criminal justice system, in Canada (Owusu-Bempah and Miller 2010). Millar and Owusu-Bempah (2011) argued that many Canadian police agencies "actively suppress" racial data when delivering their annual crime reports to Ottawa and the continued "whitewashing" of criminal data makes it virtually impossible for Canadian researchers to gauge whether police are dealing with racial and ethnic minority groups in an equitable manner. The data used in this research were obtained by the Toronto Star after a seven-year freedom of information battle that 
involved multiple appeals and counter appeals, a request for a stay by police, a trip to divisional court and a final visit to the Ontario Court of Appeal.

This data acquisition process is a perfect example illustrating the theory of 'democratic racism' which allows the combination of two seemingly incompatible sets of values: "a public commitment to racial justice and equality on one hand, but a refusal to seriously investigate and address racial inequalities and potential racial bias when these issues emerge" (Henry and Tator, 2005, p. 349; Wortley and Owusu-Bempah, 2011, p. 11). In the author's opinion, an excellent example of democratic racism in action is provided when the Toronto police swear to provide equitable service to residents from all racial background, but, at the same time, they systematically withhold the police stop data or deliberately deter the dissemination of the data that is essential to the examination and ultimate elimination of any racial bias that may exist in the police-citizen interactions.

\section{Police stops and spatial variations}

For nearly more than a decade (2001 - 2012), citizens in Toronto had witnessed stably declining crime rates across the city (Matteo 2014). Consistent with the declining crime rates, the number of stops of white youth has dropped by $28.6 \%$ while the efficiency of those stops had increased by 3.3\% during 2003 and 2012. By contrast, the number of stops of black youth had increased by $42.7 \%$ while the efficiency of those stops has declined by $44.9 \%$ during the same period. Although the stops/arrests ratio, an index to measure stop efficiency for black youth is just slightly lower than it is for white youth, but if the trend in the stops of white and black youth continues in the next 10 years (between 2013 and 2022), the vast majority of stopped youth would be black and the efficiency of those stops would be extremely low by the year of 2022 .

In addition, this paper's focus is not on the analysis of the race or ethnicity of individual stops of citizens, but on the stops/arrests ratios for black and white youth at the neighborhood level. Location becomes the focus in this study, because places like crime hot-spots have been most closely linked to the logic of policing under TPS - Policing that focuses on crime risk factors (e.g. hard-core criminals or crime hot-spots) has been found to produce more promising results in controlling crime than other traditional policing programs, such as random patrol. In other words, it is place that is the focal point of the underlying theories of problem-oriented policing and place is the unit of analysis for the allocation and deployment of police resources. The spatial analysis at the neighbourhood-level found that the areas with higher racial disparity were spatially clustered rather than dispersed, and the majority of the clusters spatially coincided with white-dominated residential areas and/or high crime-rate areas.

Excessive stops of black youth in white and/or high-crime neighbourhoods can distort the crime statistics in those areas, since this disproportionate number of stops can lead to more arrests in white dominated and/or high-crime neighbourhoods. Guided by problem-oriented policing strategies, arrest statistics ensure that even a greater number of black youth would be stopped in those neighbourhoods in the future. This will become a plausible, but self-sustained vicious cycle where police stops and arrests against black youth perpetuate each other. The persistence of disparate policing tactics in different neighborhoods has 
salient, but enormous costs for TPS and the society as a whole, such as diminishing the social good of policing and weakening its welfarist ideology (Durlauf, 2006), while making policing harder (Skogan and Frydl, 2004; Harris, 2002); the withdrawal of citizens' cooperation with the police (Tyler and Fagan, 2008; Fagan and Meares, 2008); or, in the worst case, defiance of legal and social norms (Fagan and Meares, 2008; Sherman, 1993).

\section{Policy suggestion}

Access to police data

The police agencies in Canada are committed to provide equitable service to all Canadians, but ironically they systematically withhold police stop data that is essential to the examination and ultimate elimination of race and/or place profiling that may exist in policing. Indeed, Wortley and Owusu-Bempah (2001) suggest that the ban on race crime and race-based statistics actually helped the Canadian justice system reject accusations of racial bias. For example, the Canadian courts constantly dismissed allegations of racial profiling in policing because of a lack of empirical data (see Tanovich 2006). The fact is, without access to reliable data, both qualitative and quantitative, it is impossible for researchers to accurately and timely monitor the activities of police officers on the streets, determine whether racial bias exists in police practices, and measure the extent of racial bias if it does exist. Therefore, the study calls for open and free access to police stop data collected by Canadian police agencies so that researchers can examine the issue of racially biased policing on an ongoing basis; it is easier for racial minority communities to demand accountability on the racial disparity in police stops from police agencies; and more crucially police agencies can respond to outside critics by making reforms to deter or eliminate possible misconduct.

\section{Internal review by TPS}

Given the fact that the police stop data are in the hand of TPS, it is easy for TPS to generate a periodic report showing the numbers of stops and searches, by race and place, for each police officer working in the city. Police officers who stopped significantly more minority youth than others can easily be identified, and the reasons for the disparity can be explored by following up interviews. It is strongly urged that TPS should adopt periodic internal review of 208 cards and incorporate such review as a standard part of monthly or quarterly management review. In addition, this study clearly shows that a few "bad apples" alone cannot explain the big racial disparity in police stop practices in white and/or high-crime neighbourhoods. In other words, while the racially biased policing can certainly be improved by identifying those officers who appear to be the most disparate in their actions, the issue cannot be addressed by focusing there alone. Therefore, it is suggested that TPS should utilize the growing social science research on implicit bias and systemic and institutional racism to explore how the agency as a whole created racially biased policing outcomes in so many neighbourhoods, despite intent to the opposite. Also, TPS should strengthen training and education in anti- 
racial profiling and improve efforts at changing police culture and make the public complaints process more objective, fair, and accessible (Tanovich, 2006; OwusuBempah and Millar, 2010).

\section{Hot spots policing and community policing}

The success of policing need the support and cooperation of the public to effectively combat crime and maintain social order in public spaces (Weisburd and Telep, 2014). Recent research demonstrates that hot spots policing can damage residents' perceptions of the police policies and practices (see Kochel, 2011; Rosenbaum, 2006). Rosenbaum (2006), for example, argues that enforcementoriented hot spots policing runs the risk of weakening police-community relations. Aggressive tactics can drive a wedge between the police and communities, as the latter can begin to feel like targets rather than partners. This is particularly relevant in high-crime communities where perceptions of the police already tend to be more negative (Gau and Brunson, 2010). This has implications for the crime control effectiveness of hot spots policing, since with the deteriorating support and cooperation of the public, the short-term crime control gains from hot spots policing can be offset by long-term steady increases in criminal offending (Weisburd and Telep, 2014). Therefore, the author suggests that the police should adopt alternative approaches to controlling hot spots that do not rely solely on onedimensional intensive enforcement. Of course, arresting criminal offenders is a central part of the police function and should remain an important tool in an array of responses to crime hot spots. However, to alleviate the damage caused by hot spots policing, the current study calls for placing a higher priority on community policing in Toronto.

Central to the concept of community policing, especially in a democracy society, is community control of the police through community empowerment and participation (Sklansky, 2008). The great advantage of community policing is that it is accountable to every citizen in the city. According to this principle, a community should not act as a passive receiver or observer of police services but should be an active co-producer of police services. The community must participate in and contribute to the policing decision-making process and determine the amount and the types of police services and protection. In other words, the police must take into consideration the community's needs and demands when developing a policing strategy. The police also should strive for community support before implementing the strategy, especially if there is a chance that the strategy may arouse resentment among the community members that they (or their community) are being treated in an unfair way. While the work is difficult, long-term community engagement efforts can pay large dividends in improving the quality of police-community relationships and collaborative crime prevention and reduction efforts.

\section{Conclusion}

In general, the issue of the racial disparity in police stops has not been examined as deeply in Canada as it has been in the United States. In Canada, police stop and search studies focusing on black youth and/or neighbourhood-based processes are 
very limited. Our study contributes empirically to research into police stops of black youth in Toronto and demonstrates that members of the city's police force are susceptible to racially biased policing in neighbourhoods dominated by white residents and/or having high crime rates. For deterring or eliminating possible misconduct in police stop and search practices, it is vital to identify the characteristics of the areas that place minority individuals at the high risk of being racially profiled and pass this information to the police and neighbourhood representatives so that the practice can be finally abandoned in the future (Parker et al., 2004).

As discussed in this paper, the racial disparity in police stops and searches is not an appropriate response to a high crime rate among black youth and does not represent fair police practices. Instead, excessive stops of black youth can cause irreparable harm to the relationship among members of the police force, the residents in high crime rate neighbourhoods and the racialized communities in the city. Sherman's Defiance Theory (Sherman 1993), have clearly shown that people with poor perceptions of the justice system are less likely to obey the law. Thus, racial differences in stop and search activities could ultimately contribute to racial differences in criminal behaviour. In terms of the implications for Toronto police, this study emphasizes that TPS should allow open and free access to police stop data and conduct internal review regularly based on the police stop data, since without proper data, it is impossible to truly document the extent of racial discrimination and determine whether anti-racist policies are having an impact. Also, this study suggests that policing strategies should have the support of the racialized community, and ensure effective crime control while maintaining principles of community policing.

\section{References}

Anselin, L 2003, 'Spatial Externalities, Spatial Multipliers, and Spatial Econometrics', International Regional Science Review, vol. 26, no. 2, pp. 153-166.

Beyer, HL 2004, Hawth's Analysis Tools for ArcGIS, viewed 5 June 2016 , goo.gl/9Xvuin.

Bittner, E 1970, The Functions of Police in Modern Society, National Institute of Mental Health, Rockville, MD.

Braga, A 2005, 'Hot Spots Policing and Crime Prevention: A Systematic Review of Randomized Controlled Trials', Journal of Experimental Criminology, vol. 1, no. 3, pp. 317-342.

Braga, A 2007, 'The Effects of Hot Spots Policing on Crime', Campbell Systematic Reviews, vol. 3, no. 1, pp. 1-36.

Chui, T, Tran, K \& Maheux, H 2008, Canada's Ethnocultural Mosaic: the 2006 Census, Catalogue no. 97-562-X, Statistics Canada, Ottawa.

Doerner, W 1997, An Introduction to Law Enforcement: An Insider's View, ButterworthHeinemann, New York.

Durlauf, S 2006, 'Racial Profiling as a Public Policy Question: Efficiency, Equity, and Ambiguity', American Economic Review, vol. 92, no. 2, pp.132-136.

Eid, P, Magloire, J \& Turenne, M 2011, Racial Profiling and Systemic Discrimination of Racialized Youth: Report of the Consultation on Racial Profiling and its Consequences, 
Commission des Droits de la Personne et des Droits de la Jeunesse, Montreal.

Fagan, J \& Meares, T 2008, 'Punishment, Deterrence, and Social Control: The Paradox of Punishment in Minority Communities', Ohio State Journal of Criminal Law, vol. 6, no. 1, pp. $173-229$.

Fagan, J, Geller, A, Davies, G \& West, V 2010, 'Street Stops and Broken Windows Revisited: The Demography and Logic of Proactive Policing in a Safe and Changing City', in SK Rice \& MD White (eds.) Race, Ethnicity, and Policing: New and Essential Readings, pp. 309-348, NY: New York University Press, New York.

Foster, C 1996, A Place Called Heaven: The Meaning of Being Black in Canada, HarperCollins, Toronto.

Gau, J \& Brunson, RK 2010, 'Procedural Justice and Order Maintenance Policing: A Study of Inner-city Young Men's Perceptions of Police Legitimacy', Justice Quarterly, vol. 27 no. 2, pp. 255-279.

Gelman, A, Fagan, J \& Kiss, A 2007, 'An Analysis of the New York City Police Department's 'Stop-and-Frisk' Policy in the Context of Claims of Racial Bias', Journal of the American Statistical Association, vol. 102, no. 479, pp. 813-823.

Harris, D 2002, Profiles in Injustice: Why Racial Profiling Cannot Work, New Press, New York.

Henry, F \& Tator, C 2005, The Colour of Democracy: Racism in Canadian Society, Nelson, Toronto.

James, C 1998, "Up to no Good': Black on the Streets and Encountering Police', in V Satzewich (ed), Racism and Social Inequality in Canada: Concepts, Controversies and Strategies of Resistance, pp. 157-176, Thompson, Toronto.

Kari, S 2014, 'Is Toronto Over-Policed?', Globe and Mail, viewed 5 June 2016 , https://goo.gl/FvNGKC.

Kochel, TR 2011, 'Constructing Hot Spots Policing: Unexamined Consequences for Disadvantaged Populations and for Police Legitimacy', Criminal Justice Policy Review, vol. 22, no. 3, pp. 350-374.

Matteo, L 2014, Police and Crime Rates in Canada: A Comparison of Resources and Outcomes, The Fraser Institute, Vancouver.

Meehan, A \& Ponder, M 2002, 'Race and Place: The Ecology of Racial Profiling African American Motorists', Justice Quarterly, vol. 19, no. 3, pp. 399-430.

Meng, Y 2014, 'Racially Biased Policing and Neighbourhood Characteristics: A Case Study in Toronto', CyberGeo, Canada.

Millar, P \& Owusu-Bempah, A 2011, 'Whitewashing Criminal Justice in Canada: Preventing Research through Data Suppression', Canadian Journal of Law and Society, vol. 26, no. 3, pp. 653-661.

Morton, HF 2015, 'Investigative Detention and Street Check', in ME Beare, ND Rosiers \& AC Deshman (eds), Putting the State on Trial: The Policing of Protest during the G20 Summit, pp. 168-195, UBC Press, Vancouver.

Neugebauer, R 2000, 'Kids, Cops, and Colour: the Social Organization of Policeminority Youth Relations', in R Neugebauer (ed), Criminal Injustice: Racism in the Criminal Justice System, pp. 46-59, Canadian Scholars Press, Toronto.

Ontario Human Rights Commission 2003, Paying the Price: the Human Cost of Racial Profiling, Ontario Human Rights Commission, Toronto.

Owusu-Bempah, A \& Millar, P 2010, 'Research Note: Revisiting the Collection of Justice Statistics by Race in Canada', Canadian Journal of Law and Society, vol. 25, no. 1, pp. 97-104. 
Parker, KF, MacDonald, JM, Alpert, GP, Smith, MR \& Piquero, A 2004, 'A Contextual Study of Racial Profiling: Assessing the Theoretical Rationale for the Study of Racial Profiling at the Local Level', American Behavioral Scientist, vol. 47, pp. 943-962.

Quillan, L \& Pager, D 2001, 'Black Neighbors, Higher Crime? The Role of Racial Stereotypes in Evaluations of Neighborhood Crime', American Journal of Sociology, vol. 107, no. 3, pp. 717-767.

Rankin, J \& Winsa, B 2012, 'Known to Police: Toronto Police Stop and Document Black and Brown People Far More than Whites', The Star, viewed 5 June 2016, https://goo.gl/rQ39c2.

Rankin, J \& Winsa, B 2013, 'Toronto Police Propose Purging Carding Information from Database', The Star, viewed 5 June 2016, https://goo.gl/WxIuzU.

Reiss, A 1971, The Police and the Public, Yale University Press, New Haven, CT.

Ridgeway, G \& Macdonald, J 2010, 'Methods for Assessing Racially Biased Policing', in SK Rice \& MD White (eds), Race, Ethnicity, and Policing: New and Essential Readings, pp. 180-204. New York University Press, New York, NY.

Roh, S \& Robinson, M 2009, 'A Geographic Approach to Racial Profiling: The Microanalysis and Macroanalysis of Racial Disparity in Traffic Stops', Police Quarterly, vol. 12, no. 2, pp. 137-169.

Rosenbaum, DP 2006, 'The Limits of Hot Spots Policing', in D Weisburd \& AA Braga (eds), Police innovation: Contrasting perspectives, pp. 245-263, Cambridge University Press, New York.

Sherman, LW 1993, 'Defiance, Deterrence, and Irrelevance: A Theory of Criminal Sanctions', Journal of Research in Crime and Delinquency, vol. 30, no. 4, pp. 44454473 .

Sherman, LW \& Eck, JE 2002, 'Policing for Crime Prevention', in LW Sherman, DP Farrington, BC Welsh \& DL MacKenzie (eds), Evidence-Based Crime Prevention, pp. 295-329, Routledge, New York.

Sklansky, DA 2008, Democracy and the Police, Stanford University Press, Stanford.

Skogan, W \& Frydl, K 2004, The Evidence on Policing: Fairness and Effectiveness in Law Enforcement, National Academy Press, Washington, DC.

Smith, MR, Makarios, M \& Alpert, GP 2006, 'Differential Suspicion: Theory Specification and Gender Effects in the Traffic Stop Context, Justice Quarterly, vol. 23, no. 2, pp. 271-295.

Stults, B, Parker, K \& Lane, E 2010, 'Space, Place, and Immigration: New Directions for Research on Police Stops', in SK Rice \& MD White (eds), Race, Ethnicity, and Policing: New and Essential Readings, pp. 411-434, New York University Press, New York, NY.

Tanovich, D 2006, The Colour of Justice: Policing Race in Canada, Irwin Law, Toronto. Tanovich, D 2007, 'One List for Air Travellers, One List for Black Youth', The Star, viewed 5 June 2016, https://goo.gl/kmCliL.

Thompson, A 1999, 'Stopping the Usual Suspects: Race and the Fourth Amendment', New York University Law Review, vol. 74, no. 4, pp. 956-1013.

Toronto Police Service 2010, 2010 Update to the Environmental Scan, viewed 5 June 2016, https://goo.gl/WAbAem.

Toronto Police Accountability Coalition 2012, Toronto Police 208 card, viewed 1 April 2017, https://goo.gl/4zkaC9.

Tyler, T \& Fagan, J 2008, 'Legitimacy, Compliance and Cooperation: Procedural 
Justice and Citizen Ties to the Law', Ohio State Journal of Criminal Law, vol. 6, no. 1, pp. 231-275.

Weisburd, D \& Braga, A 2003, 'Hot Spots Policing', in H Kury \& O Fuchs (eds), Crime Prevention: New Approaches, Weisner Ring, Mainz, Germany.

Weisburd, D, Mastrofski, S, McNally, A, Greenspan, R \& Willis, J 2003, 'Reforming to Preserve: Compstat and Strategic Problem Solving in American Policing', Criminology and Public Policy, vol. 2, no. 3, pp. 421-456.

Winsa, P \& Rankin, J 2012, 'Police Service Board Decision on 'Carding' Stuns Activists', The Star, viewed 5 June 2016, https://goo.gl/koywgN.

Wortley, S 2013, 'Police Stops Damage Lives of Black Torontonians', The Star, viewed 5 June 2016, https://goo.gl/EHwzJp.

Weisburd, D \& Telep, C 2014, 'Hot Spots Policing: What we know and what we need to know', Journal of Contemporary Criminal Justice, vol. 30, no. 2, pp. 200-220. 